Made available courtesy of Cognizant Communication Corporation: http://www.cognizantcommunication.com/

Tourism Analysis, Vol. 6 pp. 29-40

Printed in the USA. All rights reserved.

\title{
EXAMINING THE SOURCES OF DIFFERENTIAL SUPPORT FOR TOURISM INDUSTRY IN TWO GHANAIAN CITIES
}

\author{
ERCAN SIRAKAYA,* VICTOR TEYE, $\dagger$ and SEVIL F. SÖNMEZ† \\ *Department of Recreation, Park, and Tourism Sciences, Texas A\&M University, \\ 308 Francis Hall, College Station, TX 77843-2261 \\ $\dagger$ Department of Recreation Management and Tourism, Arizona State University, \\ P.O. Box 874905, 131 Moeur Building, Tempe, AZ 85287-4905
}

\begin{abstract}
The current article examines residents' support for tourism in the Central Region of Ghana in Africa using social exchange theory as the guiding framework. Using pooled data from the two Ghanaian communities of Cape Coast and Elmina, this article tested a research hypothesis that support for tourism varies between the two Ghanaian communities due to their differing socioeconomic bases. Findings of this study suggest differences in the levels of support for tourism (the hospitality industry and tourism infrastructure/attractions) among the residents of the two Ghanaian communities. Results of regression analyses suggest that support for the hospitality industry and support for the infrastructure and tourism attraction development were influenced by partially different reasons in both communities. The higher support for tourism in Cape Coast might be attributable to its status as the region's capital. Cape Coast, on the other hand, has a relatively more diversified economy including entities such as government offices, a university, several leading secondary schools, retail activities, and hotels; some of this diversification may be viewed as positive and directly attributed to the tourism development in the town.
\end{abstract}

Social Exchange Theory Cape Coast Elmina Ghana Africa Residents' attitudes Tourism development Tourism policy

Since the late 1980s, tourism has received considerable attention in the economic development strategy of Ghana. The number of tourist arrivals as well as tourists' expenditure has increased steadily, while both public and private investments in various tourism subsectors have expanded. The government established the Ministry of Tourism in 1993 to underscore its commitment to tourism development, and with assistance from the United Nations Development Program (UNDP) and the World Tourism Organization (WTO), prepared a 15-year Tourism Development Plan for the period 1996 to 2010. Of the 10 administrative regions in the country, the Central Region is growing to quickly become the 
leading destination in Ghana due to its diverse tourism resource base and a number of projects initiated in the last 10 years, emphasizing the development of nature-based and cultural tourism. However, no scientific studies have been conducted that would measure residents' attitudes and support for tourism.

The purpose of this article is to describe and shed light on the major factors influencing the support or the lack thereof in the two Ghanaian towns of Cape Coast and Elmina. The possible sources of similarities and differences in support for tourism development are examined using city-based discrete data. The two communities were selected for a number of reasons. First, the Central Region has increasingly become the leading tourist destination of international tourists visiting the country (Akyeampong, 1996; Teye, 1999). Second, the communities of Cape Coast and Elmina are the two major receptive destinations in the Central Region as a result of their natural and historical resources, including three World Heritage Slave Forts and Castles that are already attracting a large number of both domestic and international visitors. A significant segment of the international visitors are African Americans on spiritual, emotional, and cultural pilgrimage in search of their origins, history, and ancestry. Third, the Central Region and the two towns have been the recipients of significant international development assistance for tourism development from such organizations as the UNDP, the United States Agency for International Development (USAID), and the WTO. Finally, all these tourism development activities in the last decade resulted in a 15-Year Integrated Tourism Development Plan for the period 1996 to 2010 (Government of Ghana/WTO/UNDP, 1996) for the Central Region. Consequently, the Region as well as Cape Coast and Elmina lend themselves to studies examining residents' attitudes toward tourism development. This study is also intended to establish the benchmark for comparative studies in the future in the Central Region as well as in the other nine regions of Ghana.

\section{Literature}

To date, various factors have been found to influence residents' perceptions and attitudes. These include, but are not limited to, importance of the industry to the community, extent of individuals' reliance on the tourism industry, length of residency in the community, and the community's economic reliance on the tourism industry. Some of the specific factors include: native-born status in the community (Canan \& Hennessey, 1989; Um \& Crompton, 1987), length of residency in the community (Allen, Long, Perdue, \& Kieselbach, 1988; Liu \& Var, 1986), the extent of tourism concentration in the community (Pizam, 1978), economic reliance on the tourism industry (Madrigal, 1993), values (Lindberg, Johnson, \& Berrens, 1997) and to social representations (Pearce, Moscardo, \& Ross, 1996), and distance of residence from the central tourist zone (Belisle \& Hoy, 1980). Some of these basic factors have been utilized in extending studies on residents' attitudes and perceptions to a number of comparative studies within and between countries such as Israel (Mansfeld \& Ginosar, 1994), New Zealand and the United Kingdom (Ryan, Scotland, \& Montgomery, 1998), and Wales (Sheldon \& Var, 1984).

The bulk of research on residents' attitudes in the United States is from rural regions, "since tourism has a far more visible effect in rural areas than in urban areas and, consequently, a greater effect on rural residents" (Madrigal, 1993, p. 337). According to a recent model proposed by Jurowski, Uysal, and Williams (1997), economic gain, resource use, community attachment, and ecocentric attitudes were antecedents of perceived economic, social, and environmental impacts of tourism development. Their model further postulated that both the antecedents of tourism impact and the three categories of impacts of tourism had either indirect, direct, or both indirect and direct effects on local residents' support for tourism development. Their findings revealed that some of the identified antecedents not only had an indirect effect on support for tourism through their effect on the perceptions of the impacts of tourism, but also had a direct effect on support for various types of tourism. More recently, Dogan, Jurowski, and Uysal (2000) expanded their earlier findings by segregating the impacts into costs and benefits, and then examining the influence of the perception of the costs and benefits of tourism on support for tourism. Their study demonstrated how each factor affects the perceptions of the costs and benefits separately and showed the interplay among the factors. Moreover, it clarified their direct 
and/or causal effects on a host community's reaction toward tourism.

Many of the studies that have dealt with the issue of resident attitudes have basically focused on developed countries and have neglected, to a large extent, developing or underdeveloped nations. Ghana, an emerging tourist destination in Africa, is certainly not an exception. The scarcity of such studies in Africa can be explained by a variety of reasons, including marginalized economic development, low priority given the tourism industry by the government, political instability, lack of interest and awareness on key generating markets, and limited investment capital. Consequently, no major study has been carried out to examine residents' attitudes toward tourism development, as well as identifying any differences in attitudes that may exist between communities. According to the findings reported in a previous paper (Sirakaya, Teye, \& Sonmez, in press), residents' support for tourism development in Ghana depends on a number of sociopsychological factors such as tourists' perceptions, tourism impacts, respondents' employment status, membership in community organizations, and awareness of tourism development projects in the community. However, the extent of this support may vary among the residents of the two towns because they seem to be in differing stages in destination life cycle.

\section{Evolution of Tourism in Cape Coast and Elmina}

The main thrust of tourism development in Ghana in the last decade has been the Central Region, one of the 10 political and administrative regions of the country. Located about $10 \mathrm{~km}$ apart, Cape Coast, the regional capital, and Elmina are the primary tourist destinations in the Central Region, and serve as the location for three world heritage forts and castles (Elmina Castle, Cape Coast Castle, and Fort St. Jago), which are being rehabilitated to serve as various cultural tourism attractions. Within a $25-\mathrm{km}$ radius of the two towns are the newly developed Kakum National Park and a multiple land use beach resort development project at Brenu-Akyenin. Ostensibly, tourism is being developed in the region as a lead sector by the national government with assistance from such international organizations as the UNDP and the USAID. As a result, level of visitation to both Cape Coast and Elmina has increased substantially. Concomitant with these shifts in the supply and demand side, residents in both communities view tourism as one of the most important sectors of the overall economy. Indeed, they rank tourism as their top priority in development after education (see Table 1 for rankings of sectors according to their importance levels).

While the existence of tourism resources has enabled the planning and development of tourism in the region (Government of Ghana/WTO/UNDP, 1996), the objective is to reverse the decline in the regional economy "after losing its role in the colonial spatial organization and the subsequent postindependence restructuring of national transportation systems" (Akyeampong, 1996). Specifically, Cape Coast, until 1877, served as the political capital of the British colonial administration of the Gold

Table 1

Overall Ranking of Industries

\begin{tabular}{|c|c|c|c|c|c|c|c|c|c|c|c|}
\hline \multirow{2}{*}{$\begin{array}{l}\text { Overall } \\
\text { Ranking }\end{array}$} & \multirow[b]{2}{*}{ Sector } & \multicolumn{9}{|c|}{ Preference Ranking/Frequency } & \multirow{2}{*}{$\begin{array}{c}\text { Ranking } \\
\text { Scores }\end{array}$} \\
\hline & & 1 & 2 & 3 & 4 & 5 & 6 & 7 & 8 & (other) & \\
\hline 1 & Education & 184 & 186 & 258 & 164 & 115 & 54 & 77 & 64 & 81 & 1183 \\
\hline 2 & Tourism & 91 & 226 & 207 & 232 & 230 & 210 & 231 & 64 & 0 & 1491 \\
\hline 3 & Fishing & 92 & 204 & 285 & 228 & 180 & 228 & 175 & 64 & 90 & 1546 \\
\hline 4 & Manufacturing & 57 & 104 & 144 & 248 & 465 & 330 & 406 & 224 & 90 & 2068 \\
\hline 5 & Farming/Agriculture & 16 & 88 & 198 & 396 & 425 & 396 & 336 & 232 & 99 & 2186 \\
\hline 6 & Trading/Retail & 11 & 60 & 165 & 372 & 410 & 510 & 511 & 200 & 90 & 2329 \\
\hline 7 & Mining/Quarrying & 1 & 32 & 66 & 88 & 280 & 396 & 637 & 1256 & 288 & 3044 \\
\hline 8 & Wood products/forestry & 2 & 14 & 30 & 72 & 200 & 522 & 749 & 1408 & 117 & 3114 \\
\hline
\end{tabular}

Ranking of these sectors was obtained by asking the residents to rank these activities according to their importance. 
Coast, which later became Ghana after its 1957 independence. The loss of political and administrative status started the decline of the Central Region, and continued throughout the rest of the British colonial period. The town continued to hold on to its economic reputation as a national surf port and major trading center until 1962, when a new modern port was built at Tema near the present capital city, Accra.

In a similar historical context, Elmina was the first community in the Gold Coast to come into contact with Europeans in 1471, when the Portuguese landed to pursue the lucrative trade in gold. They built the San Jorge da Mina (St. George the Mine) Castle, which together with the Cape Coast Castle-built later by the Swedes in 1653-played a significant role in the Trans-Atlantic Slave Trade. The end of the gold and slave trades brought reversals in Elmina's economic fortune.

Recently, Bruner (1996, p. 290-291) stated that what most residents of Cape Coast and Elmina want from the tourism project are the principal economic benefits: additional sources of income through employment opportunities; improved infrastructure such as sanitation, waste disposal, and roads; and new projects such as a fishing harbor. Bruner (p. 291) indicated that funds from tourism have flowed into the local community and numerous plans have been drawn for small-scale business enterprises involving the tourist trade. Many young people in Elmina want to tap into the market by offering themselves as local guides; some have plans to sell food and crafts, while others want to provide home stays and even organize performance groups for tourists. Locals may benefit from such contacts with tourists in ways other than financial. In addition to money, they may receive gifts, while others establish friendships with tourists that continue through correspondence or traveling with tourists. In spite of these anticipated benefits, there is sufficient evidence to suggest that local residents are not involved in the project, but rather deliberately excluded from decision-making and kept away from some tourist attractions and sites. For example, residents are prohibited from entering grounds of the Castles, which are limited exclusively to visitors. Moreover, the type of support among residents in the two cities is expected to vary because Cape Coast and Elmina appear to be at different stages of the destination life cycle. Cape Coast seems to have a relatively more diversified economy and business activity compared with Elmina, and therefore is expected to draw more visitors. Thus, the study's main objective was to determine the factors that might best explain the level of support (or lack thereof) for the tourism industry in the two Ghanaian towns of Cape Coast and Elmina.

\section{Method}

Study methods were extensively described elsewhere (Sirakaya, Teye, \& Sönmez, in press). Briefly, data used in this study were gathered in Cape Coast and Elmina from January to April 1998, through personal interviews to administer survey questionnaires. To properly address the research questions of interest and to obtain the most representative sample possible, it was decided to survey 250 residents from each community using interpreters with verbal and written competencies in both English and the local Fanti languages. The research assistants were graduate students at the University of Cape Coast who also assisted with testing the survey in a pilot study conducted prior to the main fieldwork. The 250-resident sample size was based on such factors as previous studies conducted in the two communities by social science researchers at the University of Cape Coast, and the large extended family sizes, which constitute each household in Ghana. The final study sample consisted of 215 Elmina residents and 249 Cape Coast residents, resulting in an overall response rate of $86 \%$ (Elmina) and $99.6 \%$ (Cape Coast). The main challenge encountered during data collection was the eagerness and willingness of persons outside the sample frame to be interviewed or to volunteer their opinions. The survey was based on structured questions that allowed for the same question to each respondent, but provided a long open-ended section for individual comments. Along with an 85-item scale that measured general resident attitudes toward tourism in the two towns, the questionnaire contained 20 questions including a 20 -item scale measuring attitudes toward tourists and support for tourism development.

\section{Study Variables}

The measurement of attitudes to explain and predict behavior is used extensively in various social 
science disciplines (Fishbein \& Azjen, 1975; Sirakaya, 1997). Attitudes toward tourism and perceptions of tourists were measured using an 82- and 24-item scale, respectively. Space constraints do not permit a detailed discussion of the results of factor analyses regarding the independent variables but they can be requested from the authors. In summary, seven attitudinal factors toward tourism and two perceptual factors toward tourists were obtainedall of which were internally reliable — and explained a major proportion of the variance in their respective data sets. The study variables were operationalized using several scales, at different measurement levels. Dichotomous variables were coded as dummy independent variables. Table 2 displays the codes and designations of attitudinal and perceptual variables, as well as remaining independent variables.

\section{Residents' Support for the Tourism Industry (Dependent Variable)}

To obtain a measure of support for the tourism industry, tourism had to be defined for the respondents. Thirteen Likert-type items were provided to the respondents in order to obtain a measurement for the dependent variable. In this sense, the tourism sector was viewed as the summation of sectors that make it possible for people to travel to a particular destination (attractions and infrastructure) and the core sectors of tourism such as hotels, motels, and restaurants. These 13 items were entered into a varimax rotated principal component analysis in order to summarize general groups of attitudes toward support for the tourism sector. This view is consistent with the definition of the tourism industry. A cut-off point of 0.4 was used to include items

Table 2

Description of Independent Variables

\begin{tabular}{|c|c|c|}
\hline Code & Description of Independent Variables & Measurement Level \\
\hline INTERACT & Number of days interacted with tourists per week & Ratio \\
\hline BENEFITS & Perception of personal benefits gained from tourism activity & Interval (5-point Likert-type scale) \\
\hline TEMPLOYED & Employed in tourism or related industry & Nominal (dummy coded: yes or no) \\
\hline FAMEMPLOYED & Member of family employed in tourism & Nominal (dummy coded: yes or no) \\
\hline PRJAWARE & Awareness of tourism projects in the community & Interval (5-point Likert-type scale) \\
\hline INVOLVEMENT & Personal involvement in tourism development decision making process & Nominal (dummy coded: yes or no) \\
\hline CONSULT & Consultation with residents about tourism development in the community & Nominal (dummy coded: yes or no) \\
\hline DESIRE & $\begin{array}{l}\text { Desire to be involved in decision-making process about tourism } \\
\text { development in the community }\end{array}$ & Nominal (dummy coded: yes or no) \\
\hline ORGANIZATION & Membership in a community organization & Nominal (dummy coded: yes or no) \\
\hline BORN & Being born in the same city of residence & Nominal (dummy coded: yes or no) \\
\hline SEX & Gender & Nominal (dummy coded: male or female) \\
\hline AGE & Age of the respondents & Ratio \\
\hline EMPSTATUS & Employment status (employed, unemployed, or others) & Nominal (dummy coded: yes or no) \\
\hline EDUCATION & Education level & Ratio \\
\hline RESIDENT & Length of residency & Ratio \\
\hline INCOME & Annual personal income & $\begin{array}{l}\text { Ordinal (less than } 600,000 \phi ; 600,000- \\
\quad 999,999 \phi ; \text { above } 1,000,000 \phi)\end{array}$ \\
\hline ATTITUDE1 & Perceived social interaction with tourists & Anderson-Rubin Factor Scores \\
\hline ATTITUDE2 & Perceived cultural impacts of tourism & Anderson-Rubin Factor Scores \\
\hline ATTITUDE3 & Perceived welfare impacts of tourism & Anderson-Rubin Factor Scores \\
\hline ATTITUDE4 & Perceived negative interference of tourism in daily life & Anderson-Rubin Factor Scores \\
\hline ATTITUDE5 & Perceived economic costs of tourism & Anderson-Rubin Factor Scores \\
\hline ATTITUDE6 & Perceived sexual permissiveness due to tourism & Anderson-Rubin Factor Scores \\
\hline ATTITUDE7 & Perception of crowding & Anderson-Rubin Factor Scores \\
\hline $\begin{array}{l}\text { TOURISTSA } \\
\text { ( } 2 \text { factors })\end{array}$ & General perceptions of black and white tourists & Anderson-Rubin Factor Scores \\
\hline $\begin{array}{l}\text { TOURISTSB } \\
\text { (2 factors) }\end{array}$ & Perceptions of social and economic condition of black and white tourists & Anderson-Rubin Factor Scores \\
\hline
\end{tabular}

Note: ATTITUDE1 through ATTITUDE7 along with TOURISTSA (black and white) and TOURISTSB (black and white) were obtained through separate factor analyses, which are displayed in Tables 1 and 2. 
in the interpretation of a factor. Only one item of the initial 13 items describing various tourism industry sectors failed to load on any factor reflecting the homogeneity of items. Accordingly, two factors with eigenvalues equal to or greater than 1, explaining $53.4 \%$ of the variance in the original data set, were obtained. Because the purpose of the study was to compare the levels of support for tourism in two cities at different stages of tourism development, a breakdown of the same items from the aggregate sample resulted in two separate factor solutions. In order to compare, a factor solution from the aggregate data is presented along with two factor solutions in Table 3. Factor loadings suggest that items describing the support for tourism in both cities tended to load consistently on the same domains with the exceptions of one item in Elmina. Thus, the factor solution for both cities was regarded to be the same and aggregate factor solutions (see column 3aggregated sample) were used in further analyses.

To obtain an aggregate measurement for the dependent variables, we obtained scores for each factor, which are composite measures for each factor representing each dimension and which are usually used as surrogate measure for an unobserved but theoretically existing construct. In subsequent regression analyses, these factor scores were used as dependent variable measures to examine the effects of various independent variables on residents' level of support for tourism. Table 3 displays the domain descriptions, items, factor loadings, eigenvalues, and Cronbach's alpha. The two factors were labeled as follows: (Factor 1) support for tourism infrastructure and attractions and (Factor 2) support for the hospitality industry. The reliability of the variables in each factor was assessed by examining Cronbach's alpha coefficients, which were 0.86 for the first factor and 0.70 for the second, indicating that the variables exhibited strong to moderate correlations with their factor groupings and therefore may be regarded as internally consistent and stable.

To determine significant differences in residents' support for tourism in two cities, independent sample $t$-tests were performed. The test results indicated that there was a statistically significant difference between one (support of the hospitality industry-Factor 2) of the two domains, indicating that residents' support for the tourism industry differed by city (see Table 4). There was a moderate to high level of support for tourism infrastructure in both cities, with scale means of 30.85 (Cape Coast) and 30.72 (Elmina). The level of support in these two cities was not statistically different $(t=0.214, p<0.830)$. Similarly, there was a moderate to high level of support for the hospitality industry among the residents of both cities (mean ${ }_{\text {Cape }}$ Coast $=15.86$, mean $_{\text {Elmina }}=14.42$, based on a 20 -point scale). Moreover, there was a small but statistically significant difference between the residents of Cape Coast and Elmina in their support for the hospitality industry, where Cape Coast residents expressed a higher level of support $(t=4.989, p<0.001)$ than those in Elmina. Although the mean difference in relative magnitude was small, the null hypothesis,

Table 3

The Results of Factor Analysis for Dependent Variables

\begin{tabular}{|c|c|c|c|c|c|}
\hline Domain & Item Description & Factor Loadings & Eigenvalues & Cronbach's Alpha & Variance Explained \\
\hline $\begin{array}{l}\text { Support for tourism } \\
\text { infrastructure and } \\
\text { attractions }\end{array}$ & $\begin{array}{l}\text { Cultural attractions } \\
\text { Historic restoration } \\
\text { Roads/sewage } \\
\text { Museums } \\
\text { Outdoor recreation facilities } \\
\text { Wildlife/forest parks } \\
\text { Festivals/special events } \\
\text { Public transportation }\end{array}$ & $\begin{array}{l}0.827 \\
0.809 \\
0.732 \\
0.683 \\
0.673 \\
0.654 \\
0.638 \\
0.594\end{array}$ & 4.53 & 0.86 & 33.69 \\
\hline $\begin{array}{l}\text { Support for the } \\
\text { hospitality } \\
\text { industry }\end{array}$ & $\begin{array}{l}\text { Guest houses } \\
\text { Restaurants } \\
\text { Hotels/motels } \\
\text { Bars/night clubs }\end{array}$ & $\begin{array}{l}0.817 \\
0.795 \\
0.786 \\
0.442\end{array}$ & 1.88 & 0.70 & 19.70 \\
\hline
\end{tabular}

Total variance explained by aggregated data $=53.4 \%, n=464$. 
Table 4

$t$-Test Results for Equality of Means for the Support of Tourism in Two Ghana Cities

\begin{tabular}{lllccccc}
\hline & Town Name & $N$ & Mean & SD & $\begin{array}{c}t \text {-Test for Equality } \\
\text { of Means }\end{array}$ & $\begin{array}{c}\text { Sig. } \\
\text { (two-tailed) }\end{array}$ & $\begin{array}{c}\text { Mean } \\
\text { Difference }\end{array}$ \\
\hline $\begin{array}{l}\text { Support for infrastructure } \\
\quad \text { and tourism attractions }\end{array}$ & Cape Coast & 229 & 30.8515 & 6.4007 & 0.214 & 0.830 & 0.1219 \\
$\begin{array}{l}\text { Support for hospitality } \\
\quad \text { industry }\end{array}$ & Clmina & 196 & 30.7296 & 5.1304 & & & $0.000^{*}$ \\
\hline
\end{tabular}

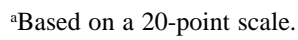

stating that no statistically significant difference existed between residents' support for tourism in two cities, was rejected (see Table 4). Hence, this difference is assumed meaningful in helping to explain the source of differential support in two cities for the hospitality industry. The level of support that the hospitality industry enjoys may be easily attributable to the visible employment benefits; in order to test this assumption and obtain a better understanding of the factors that might better explain the variation in residents' support for the tourism industry, a forward regression analysis was performed on the dependent variable: support of the hospitality industry (Factor 2).

Results of the stepwise regression are presented in Tables 5 and 6. For the first factor (residents' sup- port for tourism infrastructure and attractions), stepwise regression analyses produced two threevariable models for both Cape Coast and Elmina. For the Cape Coast model, perceived economic impacts of tourism, perceived negative interference of tourism in daily life, and membership in a community organization explained $32.9 \%$ of the variation in residential support scores. All signs of beta coefficients were theoretically correct. Perceived economic costs of tourism and interference of tourism with the daily life of a resident decreased support for tourism infrastructure and attractions, whereas belonging to a community organization increased such support in Cape Coast.

For the Elmina model, the perceptions of personal benefits from tourism activity and social interaction

Table 5

Stepwise Regression Model for the Support of the Hospitality Industry ${ }^{\mathrm{a}}$

\begin{tabular}{|c|c|c|c|c|c|c|c|}
\hline \multirow[b]{2}{*}{ Town Name } & \multirow[b]{2}{*}{ Step } & \multirow[b]{2}{*}{ Variables } & & & \multicolumn{3}{|c|}{ Forward Regression Summary } \\
\hline & & & & & $R^{2}$ & $F$-Value & Sig. \\
\hline \multirow{6}{*}{$\begin{array}{l}\text { Elmina } \\
\text { Cape Coast }\end{array}$} & 1 & Employment status (employed unemployed or others) & & & 0.058 & 5.713 & $<0.019$ \\
\hline & 1 & Awareness of tourism projects in the community & & & 0.126 & 13.814 & 0.000 \\
\hline & 2 & Length of residency & & & 0.165 & 9.407 & 0.000 \\
\hline & 3 & Consultation with residents about tourism development $\mathrm{i}$ & the com & nunity & 0.208 & 8.243 & 0.000 \\
\hline & & & \multicolumn{5}{|c|}{ Coefficients } \\
\hline & & & & $\begin{array}{l}\text { Standardized } \\
\text { Coefficients }\end{array}$ & & & $\begin{array}{c}\text { Collinearity } \\
\text { Statistics }\end{array}$ \\
\hline Town Name & Step & Variables & SE & Beta & $t$-Value & Sig. & Tolerance \\
\hline Elmina & 1 & Employment status (employed unemployed or others) & 0.828 & -0.241 & -2.390 & 0.019 & 1.000 \\
\hline \multirow[t]{3}{*}{ Cape Coast } & 1 & Awareness of tourism projects in the community & 0.321 & -0.337 & -3.644 & 0.000 & 0.986 \\
\hline & 2 & Length of residency & 0.027 & 0.253 & 2.668 & 0.009 & 0.935 \\
\hline & 3 & $\begin{array}{l}\text { Consultation with residents about tourism development } \\
\text { in the community }\end{array}$ & 0.891 & -0.216 & -2.259 & 0.026 & 0.922 \\
\hline
\end{tabular}

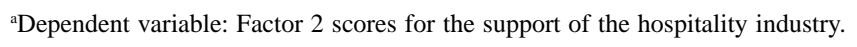


Table 6

Stepwise Regression Model for the Support of Infrastructure and Tourism Attractions ${ }^{\mathrm{a}}$

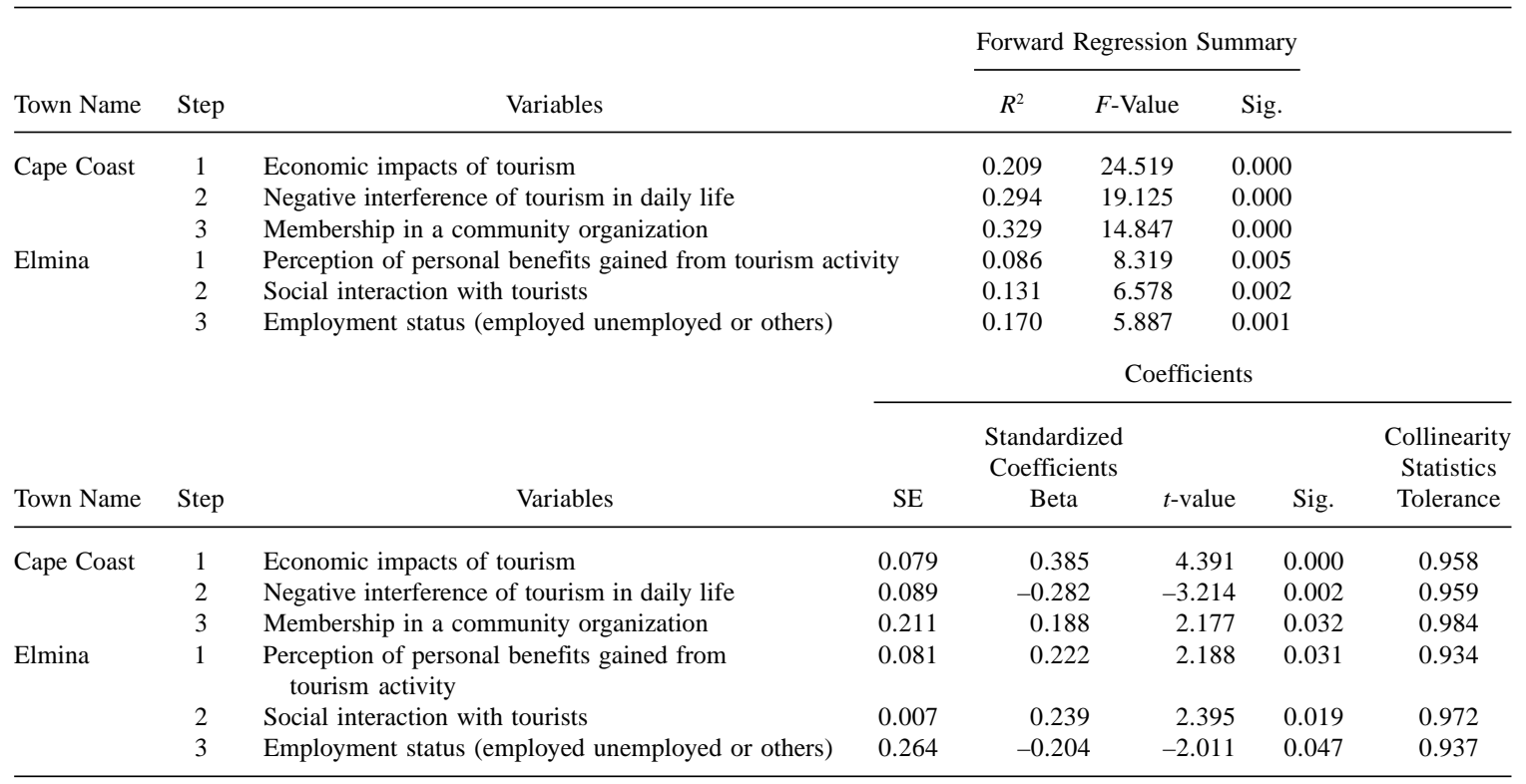

aDependent variable: Factor 1 scores for the support of infrastructure and tourism attractions.

with tourists were positive predictors of the support for tourism infrastructure and attractions. When residents believed that they personally gained from tourism activity in their community, their level of support increased as evidenced by the positive beta value $(\beta=0.222)$. Interestingly, unemployed residents were more supportive of tourism infrastructure and attractions than their employed counterpartsmainly because employed residents perceived tourism more negatively $(\beta=-0.204)$. Overall, these three variables explained $17 \%$ of the error variance in the model.

For the second factor (residents' support for the hospitality industry), the stepwise regression analysis produced a single-variable model for Elmina and a three-variable model for Cape Coast (see Table 5). For the latter, the three variables, which met the criteria and were subsequently added to the model in order of importance, were: awareness of tourism projects in the community (as a dummy variable), the length of residence, and discussion of tourism development in the community with other residents. The general model was significant at the 0.0001 probability level and explained $20.8 \%$ of the variation in resident support scores for the hospitality industry. Awareness of tourism projects ( $\beta=-0.337$ ) and discussions about tourism development with other residents $(\beta=-0.216)$ decreased the level of support for the hospitality industry in Cape Coast, whereas length of residence $(\beta=0.257)$ increased the level of support. It can be speculated that perhaps tourism projects are viewed negatively because residents do not like the way tourism (the hospitality industry) is developing in their community. When people were aware, they tended to decrease their support-everything else being constant. These results contradict findings of other similar studies, which may be due to sampling bias. Respondents may have included community leaders, active citizens who opposed tourism development due to their negative perceptions, or citizens who did not directly benefit from tourism and as a result held negative views toward it. Whichever the case might be, results suggest that careful sampling methods must be used before the validity of the social exchange theory can be discussed.

For the Elmina model, only one variable contributed to a significant explanation of the support levels that exist among the residents. Being unemployed had a positive influence on the level of support for 
the hospitality industry. The one variable, which accounted for the significant explanation of the error variance, is theoretically important because it shows the importance of tourism as a perceived job creator.

\section{Conclusion}

The purpose of this study was to determine factors that can explain the support for tourism (or its lack) between Cape Coast and Elmina residents. The two towns examined differ in terms of their economic, social, and governmental structures. Accordingly, the major premise of this article was that the extent of support for tourism varies among the residents of the two towns. To understand the extent of support for the tourism industry in the two towns and concomitantly discuss the implications of this study, it is important to understand the setting in which tourism development occurs, as well as the residents' expectations.

Beginning with the loss of a role as the political capital and seat of the colonial administration to Accra, Cape Coast and Elmina began a gradual decline into the postindependence years after 1957 . The regional economy became marginalized; the young and economically active population migrated mostly to the port city of Sekondi-Takoradi about 45 miles to the west. Others moved to either the gold mining towns of Tarkwa and Obuasi about 100 miles to the north or to Accra, the economic and political capital of the country. In the late 1980s, as a result of the introduction of Ghana's Economic Recovery Program (ERP) and the decentralization of the political administration away from Accra's central government, regional administrations were given more power to institute economic development programs. The Central Region Administration (CRA) targeted tourism as a priority area to reverse the region's economic fortunes. Two key agencies were thus established: the first, the Central Region Development Commission (CEDECOM), to coordinate all economic development activities in the region, and the second, the Tourism Development Scheme for the Central Region (TODCER), to spearhead tourism development in the region.

The residents of the Central Region, Cape Coast and Elmina in particular, were made to believe that tourism was as a panacea for their economic prob- lems. Ten years have passed since initial development efforts began and the residents have not been able to realize the promised benefits from tourism. While much has been accomplished in the areas of infrastructure development, development of attractions such as the Kakum National Park, and restorations of the slave forts and castles, actual economic benefits have not matched promises and residents' high expectations. For example, the tourism industry in the Central Region is predominantly based on organized short-tours (1- or 2-day trips) conducted by tour companies located in Accra, the country's gateway (2-hour drive from Cape Coast and Elmina). Furthermore, as a destination the Central Region lacks major attractions (except Kakum National Park and castles) and facilities that would extend the time tour groups spend in the community. The beach development for several proposed and planned resorts located $15 \mathrm{~km}$ west of Elmina at Brenu Akyenin is still at the basic infrastructure stage. Consequently, the industry is very seasonal, occupancy rates tend to be rather low, as is the economic multiplier for the region, and revenue leaks out of the community due to the weak primary and secondary economic sectors. Accra, the capital city, is the major beneficiary of tourism development in the Central Region. Additionally, wages in the tourism sector are below subsistence levels, even by Ghanaian standards, while working conditions are appalling. Most jobs in the tourism sector are in hotels, restaurants, and bars, where wages average about $\phi 60,000$ to $\phi 90,000$ a month (or about $\$ 30$ to $\$ 45$ a month) for as long as 12 hours a day over a 6-day workweek.

The contemporary socioeconomic conditions of Cape Coast and Elmina, and indeed the entire Central Region of Ghana, are succinctly stated by Akyeampong (1996) as follows:

The Central Region is therefore the typical ex-co-
lonial, sub-national region with an economic his-
tory and spatio-economic structures very similar
to other Sub-Saharan coastal regions. As other na-
tions embark on tourism promotion for local or re-
gional development purposes, they should have a
great deal to learn from the Central Region's ap-
proaches and experience. (p. 7)

The results of this study suggest that residents of the two communities have different reasons for supporting the tourism industry, as defined by two 
subsectors (tourism infrastructure/attractions and the hospitality sector). For Cape Coast, perceived economic impacts of tourism, perceived negative interference of tourism in daily life, and membership in a community organization explained a significant portion of the variation in support scores for the tourism infrastructure and attractions, while awareness of tourism projects in the community, the length of residence, and consultation with residents about tourism development played a role in explaining significant variation in residents' support for the hospitality industry. The residents of Cape Coast were neither consulted during the tourism planning process nor were they involved at the implementation stages. It has been argued by some such as Bruner (1996) that there were deliberate efforts to exclude or simply not inform residents about specifics of tourism development projects. The exclusion of residents in decision making is a very common practice in developing countries with top-down development culture, but the exclusion is even more pronounced when the tourism projects are mostly externally initiated or implemented - as appears to be the case in Ghana's Central Region. Theoretically, these findings support the basic premises of social exchange theory by confirming the earlier claims by Madrigal (1993), Perdue, Long, and Allen (1990), and Liu and Var (1986).

In the Elmina model, perceptions of personal benefits from tourism, social interaction with tourists, and employment status were the best predictors of the support for tourism infrastructure and attractions. Interestingly, employment was the single predictor that contributed to explaining the error variance in both models and was the only variable responsible in explaining the support for the hospitality industry. Being unemployed had a positive impact on the level of support for the hospitality industry. This variable is theoretically important because it shows the importance of tourism as a perceived job creator. Elmina's economy is based predominantly on fishing and the economic base is not well developed for tourism to have a significant impact on residents' life. Thus, employment prospects seem to play an important role in gaining support for the tourism development in the area.

Surprisingly, sociodemographic variables included in the models have not been able to capture the large proportion of the error variation. Although this study did not find support for including sociodemographic variables into the study of resident attitudes toward tourism, as was the case in Liu and Var's 1986 study, it is premature to dismiss these variables from further studies. Comparative studies that examine residents' attitudes toward tourism development can contribute to further evolution of the social exchange theory. More studies of residents' support for tourism in developing countries should be undertaken, if they are to benefit from the lessons learned from those destinations that preceded their stage of development.

This study adds to the literature on residents' attitudes and support for tourism in a number of areas. First, its geographical focus on Africa is a needed contribution to the literature because it has not received enough research attention in the tourism literature. Second, the thematic examination aims at understanding variations in residents' support for tourism development in small African communities that may be at the inception stage of tourism development. This is an important step because the study applied theories and models originally developed and tested in more established tourism destinations around the world, where more research has been conducted. The significance lies in providing researchers with the initial step in comparatively identifying any similarities and differences, and then analyzing the array of factors that may explain such similarities or differences in emerging tourist destinations in a country such as Ghana. Third, while this study is, admittedly, a modest beginning, it will serve as a baseline for future comparative work in the two communities, as well as potential applications to other communities in Ghana and in other African countries.

In a larger context, there are still a number of countries in Africa, such as Angola, Burundi, the Democratic Republic of the Congo, Ethiopia, Rwanda, Somalia, and The Sudan, that continue to be afflicted with impediments toward economic development. For these countries, in spite of their vast potential for tourism development, real prospects may be years away. On the other hand, several African countries (i.e., South Africa, Mozambique, Uganda, Senegal, Namibia, Botswana) have taken that first major step toward building the foundation for economic development that will invariably benefit tourism development. Examples of such steps include democratic 
reforms, privatization, structural adjustment, and commitment to planned tourism development. It is important to point out that unlike most industrialized countries where tourism is a well-established industry, African countries, for the most part, have a number of distinguishing characteristics. Many not only possess weak primary economic sectors consisting largely of unprocessed agriculture, mineral, and forestry resources and products, but also have rudimentary to nonexistent secondary or manufacturing sectors. Against this backdrop, the introduction of a mainstream tertiary activity in the form of tourism, albeit with good intentions, raises several fundamental economic development questions for the whole continent. While a detailed discussion of these issues is beyond the scope of the present article, the results from Elmina and Cape Coast point to a number of conclusions. First, in economically depressed regions and communities, residents develop high expectations from the promise of tourism development. Second, community involvement and participation is critical to the support for sustainable tourism development. These two conclusions are pretty obvious due to the body of other studies.

A critical observation made during data collection for this study needs to be shared. The majority of respondents had no clear comprehension of what constitutes tourism until the physical industry components or manifestations were explained to them. This is interesting because the Central Region of Ghana, like most of Africa, has played host to foreign visitors for centuries, beginning with the early explorers. But in Ghana, no definitive word in the local vernacular exists to describe members of the "Golden Horde" known as "tourists," and most residents during the interview hesitated, until prompted, to identify the activities that constitute tourism. It would be interesting to repeat this study in more urbanized settings (i.e., Accra) where the population is more educated and where the visitor industry is more established. Moreover, longitudinal studies are recommended to monitor the changes in residents' attitudes in both cities, especially since the tourism industry can only be expected to be successful and sustainable if destination developers and marketers continuously monitor the changes in resident attitudes and develop policies accordingly that would be sensitive to the needs of the local residents.

\section{References}

Akyeampong, O. A. (1996). Tourism and regional development in Sub-Saharan Africa: A study of Ghana's central region. University of Stockholm, Department of Human Geography.

Allen, L. R., Long, P. T., Perdue, R. R., \& Kieselbach, S. (1988). The impact of tourism development on residents' perception of community life. Journal of Travel Research, 27(1), 16-21.

Belisle, F. J., \& Hoy, D. R. (1980). The perceived impact of tourism by residents. Annals of Tourism Research, 7(1), 83-101.

Bruner, E. M. (1996). Tourism in Ghana: The representation of slavery and the return of the black diaspora. American Anthropologist, 98(2), 290-304.

Canan, P., \& Hennessy, M. (1989). The growth machine, tourism and the selling of culture. Sociological Perspectives, $32,227-243$.

Dogan, G., Jurowski, C., \& Uysal, M. (2000). A structural modeling of resident's attitudes towards tourism. Annals of Tourism Research.

Fishbein, M., \& Ajzen, I. (1975). Beliefs, attitude, intention and behavior: An introduction to theory and research. Reading, MA: Addison Wesley.

Government of Ghana/UNDP/WTO. (1996). Tourism development plan for the Central Region for 1996 to 2010. Accra, Ghana: Ministry of Tourism; Integrated Tourism Development Program.

Jurowski, C., Uysal, M., \& Williams, D. R. (1997). A theoretical analysis of host community resident reactions to tourism. Journal of Travel Research, 36(2), 3-11.

Lindberg, K., Johnson, R. L., \& Berrens, R. (1997). Contingent valuation of rural tourism development, with tests of scope and mode stability. Journal of Agricultural and Resource Economics, 22(2), 44-60.

Liu, J. C., \& Var, T. (1986). Residents attitude toward tourism impacts in Hawaii. Annals of Tourism Research, 13(2), 193-214.

Madrigal, R. (1993). A tale of tourism in two cities. Annals of Tourism Research, 20(2), 336-353.

Mansfeld, Y., \& Ginosar, O. (1994). Determinants of locals' perceptions and attitudes towards tourism development in their locality. Geoforum, 25(2), 227-248.

Pizam, A. (1978). Tourism's impacts: The social costs to the destination community as perceived by its residents. Journal of Travel Research, 16(4), 8-12.

Pearce, P. L., Moscardo, G., \& Ross, G. (1996). Tourism community relationships. Tunbridge Wells, Kent: Pergamon.

Perdue, R. R., Long, P. T., \& Allen, L. (1990). Resident support for tourism development. Annals of Tourism Research, 17(4), 586-599.

Ryan, C., Scotland, A., \& Montgomery, D. (1998). Resident attitudes to tourism development-a comparative study between the Rangitikei, New Zealand and Bakewell, United Kingdom. Progress in Tourism and Hospitality Research, 4(2), 115-130.

Sheldon, P. J., \& Var, T. (1984). Resident attitudes to tourism in North Wales. Tourism Management, 5(1), 40-47. 
Sirakaya, E. (1997). Attitudinal compliance with ecotourism guidelines. Annals of Tourism Research, 24(4), 919-950.

Sirakaya, E., Teye, V., \& Sonmez, S. (in press). Residents' support for tourism development in the central region of Ghana. Journal of Travel Research.
Teye, V. B. (1999). Tourism plans and planning challenges in Ghana. Tourism Geographies, 1(3), 283-292.

Um, S., \& Crompton, J. L. (1987). Measuring resident's attachment levels in a host community. Journal of Travel Research, 25(3), 27-29. 